\title{
Are they always bad? Assessing benefits of non-indigenous species in aquatic environment and their implications
}

\author{
Muhammad Masrur Islami* \\ Center for Deep Sea Research, Indonesian Institute of Sciences, Ambon, 97233, Indonesia
}

\section{ARTICLE INFO}

Article history:

Submitted 10 August 2020

Revised 26 October 2020

Accepted 26 November 2020

Published online 31 December 2020

\section{Keywords:}

aquaculture

aquatic environment

management approaches

non-indigenous species (NIS)

positive impacts

\section{ABSTRACT}

Non-indigenous species (NIS), non-native, or alien species are any organisms living and spreading outside their natural habitat. Many of NIS spread to a new environment accidentally, while some other species are intentionally introduced by humans to a new habitat in many different pathways, as follows: 1) release; 2) escape; 3) contaminant; 4) stowaway; 5) corridor; and 6) unaided. Threaten native biodiversity may be the most problematic impact of NIS. They can also disrupt food-web organizations and affect the ecosystem structures. Additionally, the problem is exacerbated by disagreements regarding whether or not NIS should be permitted for aquaculture production. The likelihood of NIS escaping, being released from aquaculture, and establishing in its native habitat poses a significant threat to the ecosystem and biodiversity. NIS also have positive impacts as ecosystem engineers which may increase the biodiversity of native communities. Other benefits of NIS include providing an alternative food source and supporting fisheries and aquaculture sectors. Understanding the introduction process and the impacts of NIS should be supported by effective policy frameworks and management approaches, including risk assessment, prevention and control, pathway and vector management, early detection and rapid response, eradication, and mitigation and restoration. Furthermore, the crucial efforts would be raising public awareness, improving scientific research, and developing strategy regarding biosecurity issues as consequences of the emergence of interactions complexity among NIS and other global ecological change drivers.

(C2020 Indonesian Institute of Sciences (LIPI).

\section{Introduction}

Non-indigenous species (NIS), non-native, or alien species are any organisms that are introduced by humans, accidentally or intentionally, into a new environment. Many of them succeed, living and spreading beyond their natural habitat range (Richardson et al., 2011; Pysek et al,. 2020). Unfortunately, once they occupied a new area, sometimes problems might arise. NIS can cause a range of threats to biodiversity and native ecosystems and has become a major concern for the global communities (Ruiz et al., 1997; Doherty et al., 2016; Gallardo et al., 2019). They can be described as 'invasive species' when they spread rapidly and become established in the new habitat or ecosystems and threaten native biological diversity (Richardson et al., 2003; Pysek et al., 2020). The

\footnotetext{
* Corresponding Author

Muhammad Masrur Islami muha067@lipi.go.id
}

International Union for Conservation of Nature (IUCN), the Convention on Biological Diversity (CBD), and the World Trade Organization (WTO) classified invasive species are only those non-native species that cause undesirable environmental and economic impacts (IUCN, 2000).

Despite their negative impacts, NIS may represent some benefits due to their essential ecological and economic roles include habitat alteration, or ecosystem engineering, trophic interactions, ecosystem services and alternative resources, and aquaculture purposes. This article will look at the introduction pathways and vectors of NIS into a new environment, negative and positive impacts, as well as their significances for aquaculture productions. Several examples of the policy framework and management approaches are also addressed. It will also discuss rebranding NIS and the ways we can benefit from them, especially from the aquatic environmental perspective. 


\section{Introduction Pathway and Vector}

Many NIS spread to new environments accidentally, while humans intentionally introduce some other species to a new habitat in many different pathways. Hulme et al., (2008) simplified a framework to classify the pathways of introduction into six categories based on the amount of human assistance, are as follows: (1) release, when an organism is introduced as a commodity for release; (2) escape, when an organism is introduced intentionally as a commodity but escapes unintentionally; 3) contaminant, when an organism is introduced unintentionally along with a specific commodity; 4) stowaway, when an organism is introduced unintentionally attached to or within a transport vector; 5) corridor, when an organism is introduced unintentionally through infrastructures that linked previously not connected areas; and 6) unaided, when an organism is introduced unintentionally without being interfered by humans or as natural dispersal of nonnative species across regions.

Different taxa possess a variety of introduction pathways. For instance, vertebrates in aquatic and terrestrial habitats are introduced to the new environment mainly by releases or escapes. Similarly, aquatic flora is rarely released intentionally but more frequently stowaways or escapes, which are associated with canal or river transports. Escapes also appear to be an essential pathway of introduction for aquatic invertebrates in terms of aquaculture purposes. Microscopic organisms such as bacteria, parasites, and fungi are introduced mostly as contaminants in a specific commodity. Corridors and unaided pathways are less frequently assessed in both aquatic and terrestrial environments (Hulme et al., 2008; Hulme, 2009).

Moreover, NIS is introduced to a new habitat through several vectors such as transportation and shipping activities and aquaculture pathways (Richardson et al., 2003; Hulme, 2008; Williams et al., 2018). At least, there are 15 broad categories of vectors as media for organisms to spread outside their native habitat ranges (Table 1). It is widely recognized that transportation is one of the important dispersal vectors of NIS. It is usually associated with shipping activities of animals or plants trade.
Historically, the first moment of biological invasions was started thousands of years ago. Animal and plant species have been transported and traded by humans since the end of the Middle Ages (1500 AD), a period that related to world exploration, colonialism, and the beginning of extreme changes in social structure, trade, industry, and agriculture (Preston et al., 2004; Hulme et al., 2008; Hulme, 2009). In the past decades, the maritime trade and shipping industry increase in frequency and magnitude, which lead to the accelerated rate of biological invasions in some regions (Hulme, 2009; Seebens et al., 2013).

Shipping-mediated vectors - ballast water and hull fouling - are the major pathways for unintentional introductions for many NIS worldwide (Ruiz et al. 2000; Lewis et al., 2003; Nunes et al., 2014; Bailey, 2015). In general, increasing invasion rate was associated with a high shipping intensity (Drake and Lodge, 2004). It was empirically investigated using the diversity and population level of the model fouling tunicate Botryllus schlosseri, a cosmopolitan invader of coastal marine communities (Lacoursie`re-Roussel et al., 2016).

Invasive zebra mussel Dreissena polymorpha, one of the most well-known aquatic invaders, was reported from the Laurentian Great Lake and caused negative impacts on the ecosystem both in Europe and North America (Karatayev et al., 2007; Bailey, 2015). Hallegraeff and Bolch, (1992) documented their finding of invasive dinoflagellates Alexandrium catenella and A. tamarense in ballast tanks of vessels in Australia from Japan and Korea. However, Seebens et al., (2013) revealed that immense shipping traffic in a port does not mean it has a high invasion menace. For example, North Sea ports in northern Europe are not categorized into the most threatened ports, although they have tremendous shipping activities. Different situations were found in a number of ports in Southeast Asia, the Middle East, even in the USA where were categorized as the invasion hot spots. Drake \& Lodge, (2004) hypothesized that the different invasion risks in some places might depict different priorities of study about NIS, funding, as well as habitat or ecosystem, which have a differential vulnerability to NIS introduction.

Table 1. Pathways and vectors for NIS in aquatic environment (adapted from Carlton, 2001; Bax et al., 2003; Johnston et al., 2017)

\begin{tabular}{lll}
\hline Pathway & Vector & Target taxa \\
\hline Shipping activities & Ballast water & Plankton, nekton, benthos \\
& Hull fouling & Encrusting, nesting, mobile species \\
& Solid ballast (sand, rocks, etc.) & Encrusting, benthos, meiofauna, and flora \\
Aquaculture and fisheries & Intentional release for stock enhancement & Single species \\
& Gear, stock or food movement & Various taxa \\
& Discarded nets, floats, trawls, etc. & Various taxa \\
& Discarded live packing materials & Various taxa \\
& Release of transgenic species & Single species \\
Aquarium industry & Intentional or accidental release & Aquarium fauna and flora \\
Drilling platforms & Ballast water & Plankton, nekton, benthos in sediment \\
& Hull fouling & Encrusting, nestling, mobile species \\
Canals & Species movement & Various taxa \\
Recreational boating & Hull fouling & Encrusting, nestling, mobile species \\
Floating debris & Discarded plastic debris & Encrusting, nestling, mobile species \\
Dive practices & Snorkeling and scuba gear & Bacteria, algal spores, small mobile species \\
\hline
\end{tabular}


Industry and aquaculture activities, including intentional pets aquarium and living animals trade, are other introduction pathways of NIS. Most of them are intentionally introduced to improve the value of aquaculture and cultivation enhancement.

Grosholz et al., (2015) obtained 126 NIS related to commercial aquaculture in California based on their literature study. Another study in China showed that ornamental species trades and aquaculture were two major introduction pathways that accounted for 74 species (34.7\% of invasion) and 69 species (32.4\% of invasion), respectively.

Some fast-growing NIS were found, such as marine alga Saccharina longissima and Macrocystis pyrifera, and pufferfish Takifugu rubripes which was introduced for an exclusive food market (Xiong et al., 2017). Another example is the non-native diatom Nitzschia bizertensis, which was found on mussel aquaculture in Tunisia. Based on the laboratory study, this species was able to survive and retain its toxicity through the filtration process of mussels (Bouchouicha-Smida et al., 2015; Chan and Briski, 2017).

Another introduction vector of NIS may be considered as miscellaneous pathways, mostly "unaided" such as natural dispersal and other unintentional routes. For example, floating marine debris can be a vector of NIS besides its problem, which mainly discussed the pollution perspective. Thus, it can provide a possible habitat for fouling species that might be transported to other regions by sea currents (Rech et al., 2016; Geburzi and McCarthy, 2018).

Some studies documented various species, including mollusks, bryozoans, and barnacles, settled on plastic litter, and some of them were considered as NIS (Barnes and Milner, 2005; Gil and Pfaller, 2016). Consequently, the number of NIS, especially in the aquatic environment, might increase along with the increase in amounts of marine debris.

\section{Is There any Benefit of Non- Indigenous Species?}

Most of the papers and studies about NIS generally discussed their negative impacts or harmful effects on the native community and environment. The most problematic impact is that NIS threatens native biodiversity. They can change population size, diversity, richness and abundance, and structure of native species community (Bax et al., 2003; Molnar et al., 2008; Kumschick et al., 2015; Doherty et al., 2016; Pysek et al., 2020). The European green crab Carcinus maenas is one example of NIS invaded the east coast of North America and interfered native community and population density (Griffen, 2011). The kelp Undaria pinnatifida is another NIS that caused ecological impacts on the native community. This species invaded firstly on the Mediterranean coast and now spread on the coastal area in more than 13 countries around the world (James et al., 2015; Epstein and Smale, 2017).

Both Carcinus and Undaria were included in the IUCN list of 100 of the world' $s$ worst invasive alien species (Lowe et al., 2000). NIS can also lead to the extinction of native species (Bellard et al., 2015). According to the IUCN Red List, NIS is the second most dangerous threat of species extinctions after habitat destruction. In detail, of the 680 extinct animal data, 34 cases (20\%) addressed NIS as the only cause of extinction, while 82 and 77 species cited habitat destruction and harvesting, respectively (Clavero and Garcia-Berthou, 2005).

Ecologically, NIS can also disrupt food-web structures since they can be found in all trophic levels and compete with native species for food resources (Gallardo et al., 2015; Giakoumi et al., 2019). Their impacts are also depended on their role in the trophic levels. NIS, which comes from a higher level of trophic, will have an influence on biomass and abundance of the affected native species in lower trophic levels (Gallardo et al., 2015). This situation is getting worse if there are more NIS that play a

\begin{tabular}{|c|c|c|c|}
\hline IMPACTS ON & SPECIES & ECOSYSTEM ENGINEERING & ECOSYSTEM PROCESSES \\
\hline & $\begin{array}{l}\text { - Food provisioning } \\
\text { - Providing shelter } \\
\text { from predator } \\
\text { - Ecosystem } \\
\text { engineering }\end{array}$ & $\begin{array}{l}\text { - Structural complexity } \\
\text { engineers (create or } \\
\text { modify the habitat } \\
\text { structural) } \\
\text { - Bioturbation (burrowing } \\
\text { infauna - roles in sediment }\end{array}$ & $\begin{array}{l}\text { - } \text { Novel habitat creation } \\
\text { - } \text { Modifying the sedimentation } \\
\text { - } \text { Bioturbation } \\
\text { - } \text { Contrer-feeding } \\
\text { impacts }\end{array}$ \\
\hline & $\begin{array}{ll}\text { - } & \text { Predation } \\
\text { - } & \text { Competition for } \\
\text { - } & \text { Hybridization } \\
\text { - } & \text { Disease transmission } \\
\text { - } & \text { Ecosystem } \\
\text { engineering }\end{array}$ & $\begin{array}{l}\text { flux) } \\
\text { - Chemical engineers } \\
\text { of light }\end{array}$ & $\begin{array}{l}\text { - } \text { Modifying community } \\
\text { structure } \\
\text { - Creating of novel habitat } \\
\text { - } \text { Change of water circulation } \\
\text { - } \text { Modifying the sedimentation } \\
\text { - Reducting light penetration } \\
\text { - } \text { Bioturbation, Filter-feeding }\end{array}$ \\
\hline
\end{tabular}

Figure 1. Some examples of the positive and negative impacts of NIS on species and ecosystem (modified from Nunes et al., 2014; Sladonja et al., 2018). 
role as a predator in the ecosystem because they can decrease the native community through predator-prey interactions. NIS is also reported to have negative impacts on water quality and affect their existing nutrients by turning the composition of photosynthetic species (Kettunen, 2008).

On the other hand, it should be noted that NIS - in some cases - may have positive impacts (Figure 1). Assessing this issue would be helpful to develop a better understanding of the ecological role of NIS, especially in the aquatic environment. Nunes et al., (2014) found that the benefits of NIS may be ignored. Their study revealed that about $35 \%$ of the assessed NIS were reported beneficial for other species, but the whole picture was often undefined. Most of the examples herein are at the microhabitat level, which is usually outweighed by their more devastating negative impacts on a larger scale.

The introduction of NIS may increase the biodiversity of native communities by accomodating their local habitat. For example, the invasion of Pacific oysters Crassostrea gigas on resident mussel beds Mytilus edulis in the northern Wadden Sea. There was an ecological displacement from competitive to accommodative interaction between those species (Reise et al., 2017). Furthermore, the increasing species richness will support the stability of communities and improve the resistance for further invasion (Stachowicz et al., 2002; Marraffini and Geller, 2015).

The oysters also have essential ecological impacts on the coastal ecosystem. They re-engineer the ecosystem by spatially extending habitat modification, reintroducing the structural complexity and heterogeneity (van der Zee et al., 2012), intensifying biofiltration and trophic subsidy (Epstein and Smale, 2017), and providing hard-substrate biogenic reefs as habitat for mobile, sessile, even infaunal invertebrates (Ruesink et al., 2005), and other invertebrate species through secondary settlement on their shells (Herbert etal., 2016). These biogenic reefs, therefore, may stabilize the sediments, protect intertidal habitat and prevent it from erosion (Nunes et al., 2014).

While there is evidence of ecological benefits of C. gigas on species diversity and structural complexity of intertidal habitat, there is more evidence of their negative impacts on native communities. These oysters can extensively establish large areas across coastal habitats. It can lead to the biotic homogenisation of the native communities and decrease species diversity in intertidal habitats (Smaal et al., 2009).

The colonization of $C$. gigas on soft-sediment in the Wadden Sea can also displace the native bivalves such as Macoma balthica, Scrobicularia plana, and Cerastoderma edule (Troost, 2010) even spatially suppress $M$. edulis to more unsuitable habitats and might be able to lower down the food resources (Eschweiler and Christensen, 2011). Moreover, Waser et al., (2016) investigated the impacts of C. gigas on the distribution of birds on different intertidal mussel beds in the Wadden Sea. Their results revealed that the establishment of oysters leads to the decrease of the condition of mussels, which has negative impacts on three of four mussel-eating bird species. The effects of oyster settlements on the mussel and birds populations were also previously investigated by several studies (Scheiffarth et al., 2007; Cadée, 2008a; Cadée, 2008b; Markert et al., 2013).
Although reported to have negative impacts, zebra mussels $D$. polymorpha also play an essential ecological role in the aquatic ecosystem. As a sessile suspension feeder which attaches to substrate, their filtering activity increases habitat complexity as well as water clarity which supports aquatic macrophyte growth (Ward and Ricciardi, 2007; Gallardo et al., 2015; Karatayev et al., 2015; Sladonja et al., 2018). The mussels may accommodate pelagic-benthic coupling, transferring materials, and direct connection of planktonic components on the water column to the benthos components of the ecosystem (Karatayev et al., 2015). Their enormous growth and shell accumulations also result in the formation of new habitats as well as provide shelters to other invertebrates (Minchin and White, 2014).

Similarly, the non-ecosystem engineer group of NIS also has positive ecological impacts include providing ecosystem goods and services. For instance, the invasive Chinese mitten crab Eriocheir sinensis in the Baltic Sea. Their large carapaces are proper habitat for macrofauna and flora such as barnacles and algae. Other invertebrates such as bivalves, gastropods, crustaceans, and nematodes also inhabit the hairy patches on the crabs' claws (Normant et al., 2007; Geburzi and Mc Carthy, 2018). The introduced Asian hornsnails Batillaria attramentaria (formerly referred to as $B$. zonalis and $B$. cumingi) were also identified to have positive effects on both native and introduced mudflat species. Besides the use of their shells as a habitat for other invertebrates, other facilitations include indirect grazing effects and bioturbation (Wonham et al., 2005).

Another study found that invasive red macroalga Gracilaria vermiculophylla positively affects native invertebrates such as gastropods and bivalves, which inhabit Zostera marina seagrass beds. Gracilaria provides an intermediate embedded biogenic habitat, whereas the seagrass facilitates a basal biogenic habitat for the seaweeds and invertebrates (Thomsen, 2010). The seaweeds also provide food resources for grazers, e.g., gastropod Littorina littorea, attachment space on algal branches for invertebrates, e.g. bivalves $M$. edulis, and shelter for refuges to avoid the predators, e.g. large crabs C. maenas (Norkko et al., 2000; Thomsen et al., 2007; Nyberg et al., 2009). Biomass of the invasive green alga Caulerpa taxifolia in southeastern Australia was also associated positively with the composition of the epifauna community, both species and individuals (e.g., gastropod, Batillaria australis) (Gribben et al., 2013).

Other benefits of NIS include providing alternative food sources, improving aesthetic values, and supporting fisheries and aquaculture sectors (Bax et al., 2003). For example, introduced oysters in the estuarine habitat may contribute as food for fish and other invertebrates, even for human consumption.

Furthermore, oysters may also support the production of finfish or crabs, which are economically important species (Ruesink et al., 2005). In Indonesia, non-native freshwater Nile tilapia Oreochromis spp. is an important food source and has been introduced for aquaculture purposes (CABI 2019). However, several studies revealed that the introduction of tilapias negatively affects native communities.

Nile tilapia is categorized as a "potential pest" (Simoes-Vitule, 2009). This species can reduce the habitat diversity, alter the trophic structures in the aquatic 
ecosystem, decrease the relative density and the body size of the indigenous fishes, and may influence water quality as a result of sediment bioturbation and nutrient excretion (Starling et al., 2002; Arthur et al., 2010; Zengeya et al., 2013; Gu et al., 2015; Shuai et al., 2018). In fact, there are no NIS that absolutely have positive impacts. As mentioned before, even though there are ecological or economic benefits of NIS, their subtle or long-term negative impacts should be a cause of concern for all stakeholders.

\section{NIS for Aquaculture Purposes: Can It be Approved?}

Aquaculture is the fast-growing sector of the fisheries and has become a notable contributor to food production over the past decades. Currently, it accounted for 46 percent of the total production and contributed $52 \%$ of fish consumption worldwide. It is also predicted to develop further along with the increasing demand for aquatic food (Food and Agriculture Organization of the United Nations in FAO, 2020a). Despite its crucial role in the global food industry, aquaculture may have negative impacts. One of the problems is the use and introduction of NIS for aquaculture purposes. As a result, aquaculture is often criticized for having an important role as the introduction pathway by which NIS can become established outside of their natural habitat and may influence the native biodiversity (Shelton and Rothbard, 2006; De Silva et al., 2009; Lin et al., 2015).

Approximately 5,612 records of NIS introduction were associated with aquaculture (FAO, 2020b). Some developing countries, e.g., Brazil, India, and the Philippines, also highly depend on NIS in their aquaculture sector. Similarly, the majority of the aquatic food industry in Israel is from exotic fishes (Shelton and Rothbard, 2006). Furthermore, China, the largest fish producer with a total of 35 percent of contribution to the world' $s$ fish production (FAO, 2020a), also yield at least 252 NIS in their cultivation, including fish, mollusks, crustacean, and algal species (Lin, et al. 2015; Ju et al., 2020). Generally, these species are introduced for aquaculture and support the fisheries industry due to their high reproductive rate, wide environmental tolerance, diseases resistance, and trophic adaptability (Canonico, 2005; Xu and Ming, 2018).

Moreover, the issue is further complicated by the differences of view about whether NIS can be approved or not for aquaculture production. The possibility of NIS to escape, be released from aquaculture, and establish in the native habitat may cause a serious problem to the ecosystem and biodiversity (Vitule et al., 2009; De Silva, 2012; Ju et al., 2020). Other impacts of NIS include lineal competition and predation, habitat modification, trophic disruption, growth inhibition, genetic shift, and pest or diseases introduction (Hill, 2008; Lima-Junior et al., 2018). The escape and invasion of NIS are considered as the primary concern of the world' s aquaculture industry (FAO, 2020a). In China, for instance, approximately 68 farmed NIS are reported to have escaped and established wild populations. About 52 of those species are considered to have negative impacts on the native habitat, and this number is predicted to increase in the future (Ju et al., 2020).
The intentional introduction of NIS for aquaculture purposes may include the transfer of "hitchhiking" species; any uninvited biota that is associated with or maybe translocated with the culture target species; which have been potentially harmful to fisheries production and native ecosystem (McKindsey et al., 2007; FAO, 2020a). Different from the target species, the introduction of hitchhikers was mainly unintentional. For example, protozoan Vorticella sp., scutariellid temnocephalidan (Caridinicola sp.), and bdelloid rotifer; were found associated with ornamental shrimps imported from Indonesia into the Czech Republic via international trade in 2015 (Patoka etal., 2015). McKindsey et al., (2007) reported three main groups of hitchhiking species related to shellfish aquaculture: 1) alien macrospecies, such as macroalgae, tunicates, crabs, and other bivalves; 2) alien phytoplankton, such as toxic dinoflagellates and diatom; and 3) alien parasites and disease-causing organisms, such as viruses, bacteria, protozoans, and invertebrates.

On the other hand, the situation results in a paradox in terms of global food security. The introduction of NIS for aquaculture purposes has been implementing worldwide over the last five decades (FAO, 2020a). Even though negatively causing ecological and economic problems, some exotic species remarkably contribute to the acceleration of aquaculture and aquatic food production. Non-native tilapias Oreochromis spp., for instance, play an important role in the aquaculture practices in some Asian countries, such as China, Indonesia, the Philippines, India, and Sri Lanka (De Silva et al., 2009; Arthur et al., 2010; Lin et al., 2015). Likewise, shellfish, e.g., oysters, scallops, mussels, and snails, contribute 56.3 percent of the global marine and coastal aquaculture in 2018 (FAO, 2020a).

As the fast-growing and expanding of the aquaculture industry to fulfill human needs, options and efforts will have to be implemented carefully about which species to cultivate, how to feed, what system to use, and in which habitat (Klinger and Naylor, 2012). Many approaches have been conducted on developing aquaculture systems and models which take into consideration of biosecurity and ecological sustainability. For example, some advanced cultivation systems, such as recirculating aquaculture systems, aquaponic systems, integrated multitrophic aquaculture, and offshore aquaculture, have been developed, but each system has strengths and weaknesses that should be considered (Klinger and Naylor, 2012). The application of molecular genetic tools also enhances our understanding of biological invasion in the aquaculture industry as well as its ecosystems and support their integrated management approaches accordingly (De Silva, 2012; Darling et al., 2017; Dulić et al., 2019). Modeling is another method that has the potential to assess the sustainability of aquaculture production and its impacts (Cranford et al., 2012). For instance, the Farm Aquaculture Resource Management (FARM) model was created by researchers in Europe. This model provides information about the shellfish farming industry and ecological impacts, which are essential to support farmers, managers, or regulators (Gallardi, 2014). Also, strengthening policy frameworks, management actions, and regional collaborations are crucial for the development of a sustainable aquaculture industry (Ju et al., 2020; FAO, 2020a). 


\section{Policy Framework and Management Approaches}

Management actions to control the introduction of NIS have been conducted over the last three decades in response to their fast-growing number and establishment (Bailey, 2015). These measures include prevention, control, and restoration or post-hoceradication (Hulme, 2006; Bart and Simon, 2013). In terms of the framework for biological invasion, in 1989, Canada recommended the first procedures for ballast water treatments by regulating all vessels to exchange their ballast water in the open deep-water before releasing it to the system. These guidelines were aimed to prevent the introduction of Eurasian Ruffe, which was transported unintentionally by transoceanic shipping arriving in the Laurentian Great Lakes. Together with Australia, they lifted up the ballast water issue at the International Maritime Organization (IMO) (Bailey, 2015). As a result, in 1991, IMO published Guidelines for Preventing the Introduction of Unwanted Organisms and Pathogens from Ship' s Ballast Waters and Sediment Discharges. IMO also published the 'Guidelines for Control and Management of Ships' Ballast Water to Minimize the Transfer of Harmful Aquatic Organisms and Pathogens in 1997 (Bailey, 2015; Rastegary, 2017).

In Indonesia, the government has released the legal frameworks relating to invasive species problems include Act No. 5/1990 on Conservation of Biological Diversity and its Ecosystems; Law No. 16/1992 on Animal, Fish and Plant Quarantine; Government Regulation No. 27/1999 on Environmental Impact Assessment; No. 14/2002 on Plant Quarantine; and No. 15/2002 on Fish Quarantine, respectively. Then, Law No. 32/2009 on Environmental Protection and Management; Law No. 45/2009 amending Law No. 31/2004 concerning fisheries. There are also technical regulations at the ministry level, such as the regulation of the Minister of Marine Affairs and Fisheries No. 41/2014 on Import Prohibition of Hazardous Fish Species from Overseas into Indonesia Territory; and No. 9/2020 concerning Fisheries Management Area. Although there are many regulations, the government needs to reinforce the management implementation of NIS and their research priorities which hitherto are very limited.

In the context of management of NIS, there are five areas of management approaches that are essential and should be considered: risk assessment, pathway and vector management, early detection and rapid response, eradication, and mitigation and restoration (Pysek and Richardson, 2010). Risk assessment is the initial stage of the risk management process of NIS. It includes prevention which means any rational approaches conducted before the introduction of NIS. This action is often recommended and a more cost-effective strategy than managing NIS after the invasion (Simberloff, 2006; Pysek and Richardson, 2010; Faulkner et al., 2017). Prevention can be focussed on two aspects, i.e., speciescentered and pathways-centered approaches (Hulme, 2006).

In the species-centered approach, identification of NIS taxa is conducted, usually by assessing their risk and then their prevention strategies. This effort, however, has some problems such as requiring data support, facing difficulties to identify traits prediction, and the developed approaches have not been assessed for all taxa (Hulme, 2006; Kumschick and Richardson, 2013). On the other hand, the pathway-centered approach is likely more useful. It focuses on how NIS is introduced and then develops early detection strategies based on the specific introduction pathways and vectors (Hulme, 2006). Once introduction pathways and vectors of NIS are recognized, some suitable approaches can be implemented based on the targeted management (Pysek and Richardson, 2010). Furthermore, any attempt at risk assessment needs to consider: the different stages of invasion (whether it looks at the risk of early introduction of NIS); taxa difference (e.g., vertebrates and invertebrates) (Kolar and Lodge, 2002); ecosystem specificity (e.g., freshwater and marine); or impact types (Kumschick and Richardson, 2013).

Early detection and rapid response strategies are, therefore, another essential step dealing with NIS management. The problem is that - in many cases - NIS are challenging to detect, identify, and map because they may spread from all over the world. The need for taxonomy in invasion biology is also crucial to prevent misidentification of NIS that can lead to further serious problems (Pysek and Richardson, 2010). Meanwhile, control and eradication can be achieved when early detection and rapid response of NIS are well implemented. These efforts can be conducted in some standard practices include mechanical, chemical, and biological approaches. The two first methods often pose a limitation related to how large the area of invasion. Mechanical or physical removal of NIS is more effective at smaller scales of invasion, whereas chemical treatments such as biocides and chlorine are usually be implemented only in limited patches (sites or individual organisms). Therefore, biological treatments include biocontrol and ecological approaches, maybe a more appropriate effort to eradicate NIS, although there is also potential harm to non-target species (Hulme, 2006; Guo et al., 2018).

Mitigation and restoration initiatives are other efforts associated with ecological approaches in managing NIS. According to Guo et al., (2018), this approach has two main aspects: (1) restoring native species and (2) manipulating biomass of the restored community to achieve and sustain population size. Mostert et al., (2018) developed a multi-criterion approach to improve a framework of restoration. The criteria include the major NIS threat to the area, density and time frame of invasion, area size, and disturbance level. This approach would be useful if it is well-planned and implemented. Also, Hulme, (2006) suggested that the management approach of NIS should comprehensively consider six key aspects: i) the expected effects to the environment and economy; ii) the technical alternatives available to management; iii) the ease to define which the species can be targeted; iv) the risks related to the management options; v) likelihood of success in eradication, containment or control; and (vi) the degree of public concern and stakeholder interest. More importantly, those approaches should be conducted along with surveillance and monitoring in every stage of management (Cook et al., 2016), including by engaging the public as the crucial role of citizen science and increasing their understanding and awareness of biosecurity issues (Pysek et al., 2020). Therefore, management strategy is a holistic approach (Figure 2) that includes the knowledge of invasion stages, prevention, as well as long-term management of NIS and their surveillance (Geburzi and McCarthy, 2018). 


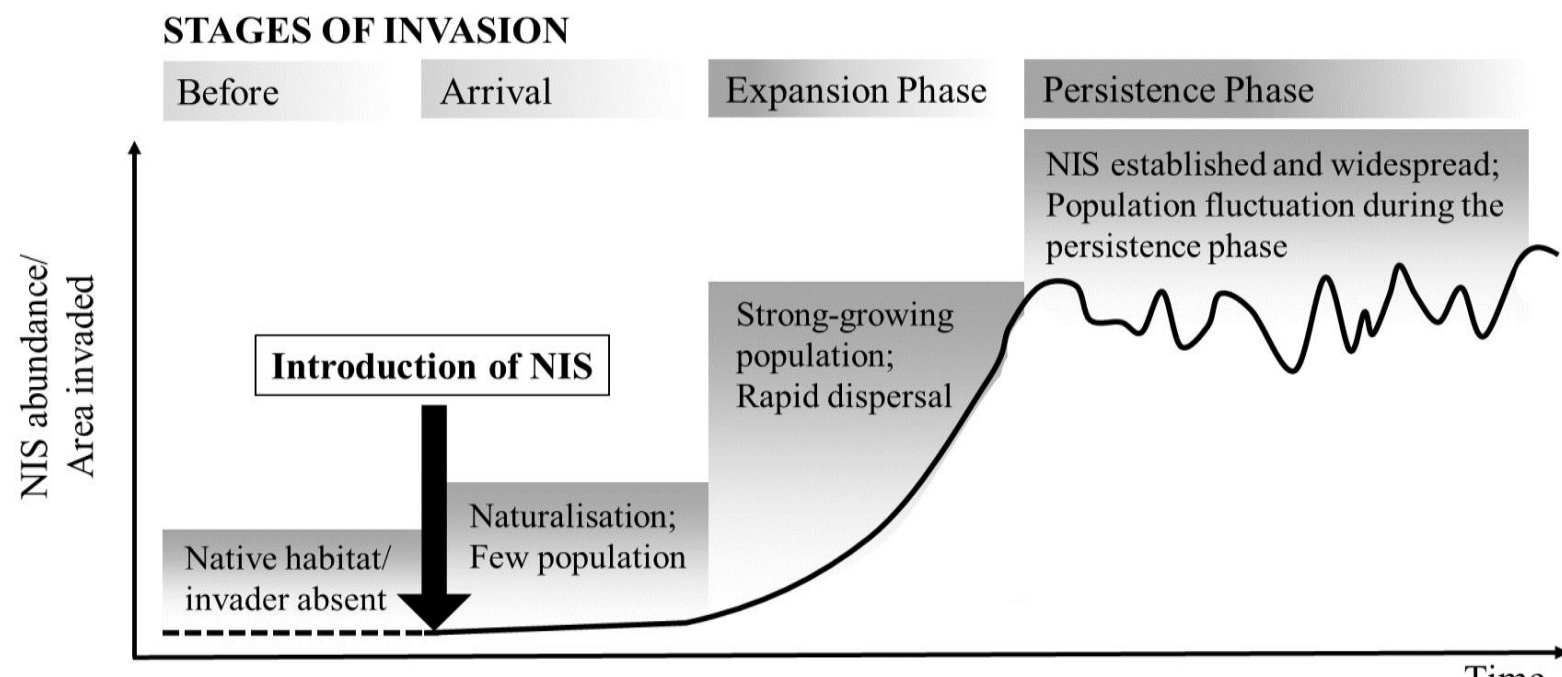

Time

MANAGEMENT STRATEGY

\begin{tabular}{|c|c|c|c|}
\hline Prevention & Eradication & Containment & Long-term Management \\
\hline $\begin{array}{l}\text { Risk assessment; } \\
\text { Pathways \& } \\
\text { vectors } \\
\text { management }\end{array}$ & $\begin{array}{l}\text { Rapid } \\
\text { response; } \\
\text { Eradication } \\
\text { measures }\end{array}$ & $\begin{array}{l}\text { Prevention for } \\
\text { further invasion; } \\
\text { Involving public } \\
\text { awareness }\end{array}$ & $\begin{array}{l}\text { Minimize impacts of NIS; } \\
\text { Mitigation \& restoration; Post-hoc } \\
\text { eradication }\end{array}$ \\
\hline
\end{tabular}

SURVEILLANCE AND MONITORING

Figure 2. Stages of invasion of NIS and their management strategy includes surveillance and monitoring of the efforts (modified from Boudouresque et al., 2005; Geburzi and McCarthy, 2018)

\section{Rebranding Non-indigenous Species: Is It Possible?}

Generally, there is "a kind of militaristic attitude toward invading species" (Briggs, 2007) among the environmental management community. This situation may prevent the objectivity of examination of species invasion impacts (Craig, 2010). Furthermore, it has been suggested that the attitude to accept NIS in 'novel ecosystem' and rationalize defeat or conciliation should be involved by the environmental management as a course of action in the future (Caroll, 2010). People's perspective is a key factor to reframe thinking by which NIS is also associated with the ecological significances, including the negative, neutral, or positive impacts (Shackleton et al., 2019). Even though in low percentage (less than $50 \%$ coverage of the NIS assessed), media publications also influenced the perception of the "worst" of NIS, and it was related to the number of scientific research for NIS (Geraldi et al., 2019).

Despite implemented many ecological approaches, managing NIS should also consider the local knowledge as a crucial aspect in developing integrative strategies that could benefit their implementation. (Bart and Simon, 2013). Engaging local communities and stakeholders play a crucial role in ensuring the outcomes of NIS management (Caceres-Escobar et al., 2018). Perception of invasion biology should not only focus on the impacts but also on their social perspective, value and beliefs, and benefits provided by NIS (Hanley and Roberts, 2019;
Kapitza et al., 2019; Potgieter et al., 2019). For instance, public denial of mitigation or eradication of NIS may be because the target species (e.g., fish, livestock) is beneficial for them (Glen et al., 2013). Although it can be challenging, involving local values can prevent the rejection of the public to the management actions as well as can educate them about the knowledge of ecological and economic impacts of the targeted NIS (Vane and Runhaar, 2016).

As mentioned previously, some NIS are also farmed for aquaculture purposes. This situation will be a dilemma as it will lead to severe risks and may deteriorate native ecosystems, economies, and human well-being (Ju et al., 2020). Thus, stakeholders, including governments, managers, even the public, should consider short and long-term impacts and benefits that arise from NIS, and their management strategies (Caroll, 2010), because it is not possible to totally recover their negative impacts. Moreover, there are other pressures than NIS would for anthropogenic activities, pollution, overfishing, mindless development, and global climate change. All of those are evidently to destruct habitat and reduce species population (Craig, 2010; Caroll, 2010; Thomas, 2013; Russell and Blackburn, 2017). Therefore, the crucial efforts would be raising public awareness, improving scientific research priorities, and developing strategies on both local and global scales regarding biosecurity issues as consequences of the emergence of interactions complexity among NIS and other global ecological change drivers. 


\section{Conclusion}

Many NIS spread accidentally to new environments, while others are deliberately introduced to new habitats by humans via various mechanisms. Native biodiversity loss may be the most serious consequence of NIS. Additionally, they can destabilize food webs and alter the structure of ecosystems. Additionally, NIS has beneficial effects as ecosystem engineers, which may increase native community biodiversity. Among the additional benefits of NIS are providing a substitute food source and supporting fisheries and aquaculture. Understanding the process of NIS introduction and its consequences requires effective policy frameworks and management approaches, which include risk assessment, prevention and control, pathway and vector management, early detection and rapid response, eradication, and mitigation and restoration. Additionally, critical efforts would be made to increase public awareness, advance scientific research, and develop a strategy for biosecurity issues that arise due to the complexity of interactions between NIS and other global ecological change drivers.

\section{Acknowledgment}

The author would like to thank Barbara Wiechecki and Paul Jennings from IALF Education for Development, Jakarta, for their comments and feedback in the initial writing process, which significantly improved this manuscript; to the peers from AAS-6M intake 2020 for whose critical thinking enriched the contents given. Thanks are also extended to two anonymous reviewers for thoughtful comments and suggestions.

\section{References}

Arthur, R.I., Lorenzen, K., Homekingkeo, P., Sidavong, K., Sengvilaikham, B., and Garaway, C.J. (2010). Assessing impacts of introduced aqua- culture species on native fish communities: Nile tilapia and major carps in SE Asian freshwaters. Aquaculture, 299, 81-88. https://doi.org/ 10.1016/j.aquaculture.2009.11.022

Bailey, S. (2015). An overview of thirty years of research on ballast water as a vector for aquatic invasive species to freshwater and marine environments. Aquatic Ecosystem Health \& Management, 18(3): 1-8. doi: 10.1080/14634988.2015. 1027129

Barnes, D.K.A. and Milner, P. (2005). Drifting plastic and its consequences for sessile organism dispersal in the Atlantic Ocean. Marine Biology, 146: 815-825. doi 10.1007/s00227004-1474-8

Bart, D. and Simon, M. (2013). Evaluating local knowledge to develop integrative invasive-species control strategies. Hum Ecol, 41: 779-788. doi 10.1007/s10745-013-9610-z

Bax, N., Williamson, A., Aguero, M., Gonzalez, E. and Geeves, W. (2003). Marine invasive alien species: a threat to global biodiversity. Marine Policy 27: 313-323. doi:10.1016/S0308597X(03)00041-1

Bellard, C., Cassey, P. and Blackburn, T.M. (2016). Alien species as a driver of recent extinctions. Biol. Lett. 12: 20150623. http://dx.doi.org/10.1098/rsbl.2015.0623

Bouchouicha-Smida, D., Bates, S.S., Lundholm, N. et al. (2015). Viability, growth and domoic acid toxicity of the diatom Nitzschia bizertensis following filtration by the mussel Mytilus sp. Marine Biology. 162:2513-2519. doi:10.1007/ s00227-015-2758-x
Boudouresque, C.F. Ruitton, S. Verlaque, M. (2005). Large-scale disturbances, regime shift and recovery in littoral systems subject to biological invasions. In: Velikova V., Chipev $\mathrm{N}$. (eds). Unesco-Roste/ BAS Workshop on regime shifts, 14-16 June 2005, Varna, Bulgaria. 85-101.

Briggs, J.C. (2007). Marine biogeography and ecology: invasions and introductions. J Biogeogr, 34:193-198

CABI - Centre for Agriculture and Bioscience International. (2019). Datasheet Oreochromis niloticus (Nile tilapia), <https://www.cabi.org/isc/datasheet/72086>, retrieved on 27 November 2019.

Caceres-Escobar, H., Kark, S., Atkinson, S.C. (2018). Integrating local knowledge to prioritise invasive species management. People and Nature, 1:220-233. doi: 10.1002/pan3.27

Cadée, G.C. (2008a). Oystercatchers Haematopus ostralegus catching Pacific oysters Crassostrea gigas. Basteria, 72:25-31

Cadée, G.C. (2008b). Herring gulls feeding again on Pacific oysters Crassostrea gigas in the Dutch Wadden Sea near Texel. Basteria, 72:33-36

Canonico, G.C., Arthington, A., McCrary, J.K., Thieme, M.L. (2005). The effects of introduced tilapias on native biodiversity. Aquatic Conserv: Mar. Freshw. Ecosyst., 15: 463-483.

Caroll, S.P. (2010). Conciliation biology: the eco-evolutionary management of permanently invaded biotic systems. Evolutionary Applications, 4: 184-199. doi:10.1111/j.17524571.2010.00180.x

Carlton, J.T. (2001). Introduced species in US coastal waters: environmental impacts and management priorities. Arlington, Virginia: Pew Oceans Commission.

Chan, F.T. and Briski, E. (2017). An overview of recent research in marine biological invasions. Mar Biol. 164: 121. doi 10.1007/s00227-017-3155-4

Clavero, M. and Garcia-Berthou, E. (2005). Invasive species are a leading cause of animal extinctions. Trends in Ecology and Evolution, 20(3): 110. doi:10.1016/j.tree.2005.01.003

Cook, E.J., Payne, R.D., Macleod, A.K. and Brown, S.F. (2016). Marine biosecurity: protecting indigenous marine species. Research and Reports in Biodiversity Studies, 5: 1-14

Craig, M.T. (2010). Pattern versus process: broadening the view of marine invasive species. Mar Biol, 157:2127-2128. doi 10.1007/s00227-010-1491-8

Cranford, P.J., Kamermans, P., Krause, G., et al. (2012). An ecosystem-based approach and management framework for the integrated evaluation of bivalve aquaculture impacts. Aquacult Environ Interact, 2: 193- 213.

Darling, J.A., Galil, B.S., Carvalho, G.R. (2017). Recommendations for developing and applying genetic tools to assess and manage biological invasions in marine ecosystems. Marine Policy, 85:54-64. https://doi.org/10.1016/j.marpol.2017.08. 014

De Silva, S.S., Nguyen, T.T.T., Turchini, G.M., Amarasinghe, U.S., and Abery, N.W. (2009) Alien species in aquaculture and biodiversity: a paradox in food production. Ambio, 38: 24-28.

De Silva, S.S. (2012). Aquaculture: a newly emergent food production sector-and perspectives of its impacts on biodiversity and conservation. Biodiversity Conservation, 21: 3187-3220.

Doherty, T.S., Glen A.S., Nimmo, D.G., Ritchie, E.G. and Dickman, C.R. (2016). Invasive predators and global biodiversity loss. PNAS 113 (40): 11261-11265.

Drake, J.M. and Lodge, D.M. (2004). Global hot spots of biological invasions: Evaluating options for ballast-water management. Proc Biol Sci, 271(1539): 575-580

Dulić, Z., Rašković, B., Marić, S. and Østbye, T-K.K. (2019). Application of Molecular Methods in Aquaculture and Fishery. In: Vucelić Radović, B., Lazić, D. and Nikšić, M. (eds.) Application of Molecular Methods and Raman 
Microscopy/Spectroscopy in Agricultural Sciences and Food Technology, pp. 119-139. London: Ubiquity Press. doi: https://doi.org/10.5334/bbj.h. License: CC-BY 4.0

Eschweiler, N. and Christensen, H.T. (2011). Trade-off between increased survival and reduced growth for Blue mussels living on Pacific oyster reefs. Journal of Experimental Marine Biology and Ecology, 403: 90-95

Epstein, G. and Smale, D.A. (2017). Undaria pinnatifida: A case study to highlight challenges in marine invasion ecology and management. Ecology and Evolution, 1-19. doi: 10.1002/ece3. 3430

FAO. (2020a). The State of World Fisheries and Aquaculture 2020. Sustainability in action. Rome, 224 pp. https://doi.org/ 10.4060/ca9229en

FAO. (2020b). Database on introductions of aquatic species. Retrieved from http://www.fao.org/fishery/introsp/search/ en (Accessed on 14 November 2020)

Faulkner, K.T., Robertson, M.P., Rouget, M. and Wilson, J.R. (2016). Understanding and managing the introduction pathways of alien taxa: South Africa as a case study. Biol Invasions, 18:7387. doi 10.1007/s10530-015-0990-4

Gallardi, D. (2014). Effects of Bivalve Aquaculture on the Environment and Their Possible Mitigation: A Review. Fish Aquac J., 5: 105. doi: 10.4172/2150-3508.1000105

Gallardo, B., Clavero, M., Sanchez, M.I. and Vila, M. (2015). Global ecological impacts of invasive species in aquatic ecosystems. Global Change Biology, 1-14. doi: 10.1111/gcb.13004

Gallardo, B. Bacher, S. Bradley, B., Comín, F.A., Gallien, L., Jeschke, J.M., Sorte, C.J.B. and Vilà, M. (2019). InvasiBES: Understanding and managing the impacts of invasive alien species on biodiversity and ecosystem services. NeoBiota 50: 109-122. doi: 10.3897/neobiota.50.35466

Geburzi, J.C. and McCarthy, M.L. (2018). How Do They Do It? Understanding the Success of Marine Invasive Species. In Jungblut, S. et al. (Eds.), Youmares 8 - Oceans across boundaries: learning from each other. p. 109-125. http://doi.org/10.1007/978-3-319-93284-2_8

Geraldi, N.R., Anton, A., Lovelock, C.E. and Duarte, C.M. (2019). Are the ecological effects of the "worst" marine invasive species linked with scientific and media attention? PIOS ONE 14(4): e0215691. https://doi.org/10.1371/ journal.pone.0215691

Gil, M.A. and Pfaller, J.B. (2016). Oceanic barnacles act as foundation species on plastic debris: implications for marine dispersal. Scientific Reports, 6: 19987. doi: 10.1038/ srep19987

Giakoumi, S., Katsanevakis, S., Albano, P.G. et al. (2019). Management priorities for marine invasive species. Science of the Total Environment688: 976-982. https://doi.org/10.1016 /j.scitotenv.2019.06.282

Glen, A.S., Atkinson, R., Campbell, K.J., et al. (2013). Eradicating multiple invasive species on inhabited islands: The next big step in island restoration? Biological Invasions, 15, 25892603. https://doi.org/10.1007/s10530-013-0495-y

Gribben, P.E., Byers, J.E., Wright, J.T. and Glasby, T.M. (2012). Positive versus negative effects of an invasive ecosystem engineer on different components of a marine ecosystem. Oikos, 122: 816-824. doi: 10.1111/j.1600-0706.2012.20868.x

Griffen, B.D. (2011). Ecological impacts of replacing one invasive species with another in rocky intertidal areas. In: B.S. Galil et al. (eds.), In the Wrong Place - Alien Marine Crustaceans. Distribution, Biology and Impacts, Invading Nature - Springer Series in Invasion Ecology 6, p. 687-701. doi 10.1007/978-94007-0591-3_25

Grosholz, E.D., Crafton, R.E., Fontana, R.E., Pasari, J.R., Williams, S.L. and Zabin, C.J. (2015). Aquaculture as a vector for marine invasions in California. Biol Invasions 15 pp. doi 10.1007/s10530-014-0808-9
Gu, D.E., Ma, G.M., Zhu, Y.J., et al. (2015). The impacts of invasive Nile tilapia (Oreochromis niloticus) on the fish- eries in the main rivers of Guangdong Province, China. Biochemical Systematics and Ecology, 59, 1-7. https://doi.org/10.1016/j. bse.2015.01.004

Guo, Q., Brockway, D.G., Larson, D.L., Wang, D. and Ren, H. (2018). Improving ecological restoration to curb biotic invasion - a practical guide. Invasive Plant Sci Manag., 11:163-174. doi: 10.1017/inp.2018.29

Hallegraeff, G.M. and Bolch, C.J., (1992). Transport of diatom and dinoflagellate resting spores in ships ballast water implications for plankton biogeography and aquaculture. Journal of Plankton Research, 14(8): 1067-1084.

Hanley, N. and Roberts, M. (2019). The economic benefits of invasive species management. People and Nature, 1:124-137. doi: $10.1002 / \operatorname{pan} 3.31$

Herbert, R.J.H., Humphreys, J., Davies, C.J., et al. (2016). Ecological impacts of non-native Pacific oysters (Crassostrea gigas) and management measures for protected areas in Europe. Biodivers. Conserv. 31pp. doi:10.1007/s10531-016-1209-4

Hill, J.E. (2008). Non-native Species in Aquaculture: Terminology, Potential Impacts, and the Invasion Process. SRAC Publication, 4303: $1-7$.

Hulme, P.E. (2006). Beyond control: wider implications for the management of biological invasions. Journal of Applied Ecology, 43: 835-847

Hulme, P.E., Bacher, S., Kenis, M. et al. (2008). Grasping at the routes of biological invasions: a framework for integrating pathways into policy. Journal of Applied Ecology 45 , 403414. doi: $10.1111 / \mathrm{j} .1365-2664.2007 .01442 . x$

Hulme, P.E. (2009). Trade, transport and trouble: managing invasive species pathways in an era of globalization. Journal of Applied Ecology 46, 10-18. doi:10.1111/j.1365-2664.2008. 01600.x

IUCN (International Union for Conservation of Nature) (2000). Guidelines for the prevention of biodiversity loss caused by alien invasive species. IUCN, Gland: 25 pp.

James, K., Kibele, J., and Shears, N. T. (2015). Using satellitederived sea surface temperature to predict the potential global range and phenology of the invasive kelp Undaria pinnatifida. Biological Invasions, 17(12): 3393-3408.

Johnston, E., Dafforn, K.A., Clark, G.F., Rius, M. and Floer, O. (2017). How anthropogenic activities affect the establishment and spread of non-indigenous species post-arrival. In: Hawkins S.J., Evans A.J., Dale A.C., Firth L.B., Hughes D.J. and Smith I.P. (eds.). Oceanography and Marine Biology an Annual Review. Vol. 55: 2-33

Ju, R-T., Li, X., Jiang, J-J., et al. (2020). Emerging risks of non-native species escapes from aquaculture: Call for policy improvements in China and other developing countries. $J$ Appl Ecol., 57:85-90. https://doi.org/10.1111/1365-2664. 13521

Kapitza, K., Zimmermann, H., Martín-López, B. and von Wehrden, H. (2019). Research on the social perception of invasive species: a systematic literature review. NeoBiota, 43: 47-68. doi: 10.3897/neobiota.43.31619

Karatayev, A.Y., Boltovskoy, D., Padilla, D.K. and Burlakova, L.E. (2007). The invasive bivalves Dreissena polymorpha and Limnoperna fortunei: parallels, contrasts, potential spread and invasion impacts. Journal of Shellfish Research, 26(1): 205-213

Karatayev, A.Y., Burlakova, L.E. and Padilla, D.K. (2015). Zebra versus quagga mussels: a review of their spread, population dynamics, and ecosystem impacts. Hydrobiologia, 746:97112. doi 10.1007/s10750-014-1901-X

Kettunen, M., Genovesi, P., Gollasch, S., et al. (2008). Technical support to EU strategy on invasive species (IAS) - Assessment of the impacts of IAS in Europe and the EU (final module 
report for the European Commission). Institute for European Environmental Policy (IEEP), Brussels, Belgium. 44 pp.

Klinger, D. and Naylor, R. (2012) Searching for solutions in aquaculture: Charting a sustainable course. Annu. Rev. Environ. Resourc., 37:247-76. doi: 10.1146/annurev-environ -021111-161531

Kolar, C.S. and Lodge, D.M. (2002). Ecological predictions and risk assessment for alien fishes in North America. Science, 298, 1233-1236

Kumschick, S. and Richardson, D.M. (2013). Species-based risk assessments for biological invasions: advances and challenges. Diversity and Distributions, 19: 1095-1105. doi: $10.1111 /$ ddi.12110

Kumschick, S., Bacher, S., Evans, T., Markova, Z., Pergl, J., Pysek, P., Vaespetignat, S., Van Der Veer, G., Vila, M. and Nentwig, W. (2015). Comparing impacts of alien plants and animals using a standard scoring system. Journal of Applied Ecology 52, 552-561.

Lacoursie`re-Roussel, A., Bock, D.G., Cristescu, M.E., Guichard, F. and McKindsey, C.W. (2016). Effect of shipping traffic on biofouling invasion success at population and community levels. Biol Invasions 15 pp. doi 10.1007/s10530-016-1258-3

Lewis, P.N., Hewitt, C.L., Riddle, M. and McMinn, A. (2003). Marine introductions in the Southern Ocean: an unrecognised hazard to biodiversity. Marine Pollution Bulletin. 46: 213-223

Lima Junior, D.P., Magalhães, A.L.B., Pelicice, F.M., et al. (2018). Aquaculture expansion in Brazilian freshwaters against the Aichi Biodiversity Targets. Ambio, 47, 427-440. https:// doi.org/10.1007/s13280-017-1001-z

Lin, Y.P., Gao, Z.X., and Zhan, A.B. (2015). Introduction and use of non-native species for aquaculture in China: Status, risks and management solutions. Reviews in Aquaculture, 7, 28-58. https://doi.org/10.1111/raq.12052

Lowe, S., Browne, M., Boudjekas, S., and De Poorter, M. (2000). 100 of the World's Worst Invasive Alien Species. The Invasive Species Specialist Group (ISSG) a specialist group of the Species Survival Commission (SSC) of the World Conservation Union (IUCN), 11 pp.

Markert, A., Esser, W., Frank, D., Wehrmann, A., Exo, K-M. (2013). Habitat change by the formation of alien Crassostrea-reefs in the Wadden Sea and its role as feeding sites for waterbirds. Estuarine, Coastal and Shelf Science 131: 41-51, https://doi. org/10.1016/j.ecss.2013.08.003

Marraffini, M.L. and Geller, J.B. (2015). Species richness and interacting factors control invasibility of a marine community. Proc. R. Soc. B 282: 20150439. http://dx.doi.org/ 10.1098/rspb.2015.0439

McKindsey, C.W., Landry, T., O' Beirn, F.X., and Davies, I.M. (2007). Bivalve aquaculture and exotic species: a review of ecological considerations and management issues. Journal of Shellfish Research, 26(2):281-294

Minchin, D. and White, B. (2014). A rapid assessment method for an invasive mollusc in an Irish lake. Management of Biological Invasions, Vol. 5(1): 63-72. doi: http://dx.doi.org/10.3391/ mbi.2014.5.1.06

Molnar, J.L., Gamboa, R.L., Revenga, C. and Spalding, M.D. (2008). Assessing the Global Threat of Invasive Species to Marine Biodiversity. Frontiers in Ecology and the Environment, Vol. 6(9): 485-492

Mostert, E., Gaertner, M., Holmes, P.M., O'Farrell, P.J. and Richardson, D.M. (2018). A multi-criterion approach for prioritizing areas in urban ecosystems for active restoration following invasive plant control. Environmental Management, 62:1150-1167. doi: 10.1007/s00267-018-1103 $-9$

Norkko, J., Bonsdorff, E., Norkko, A. (2000). Drifting algal mats as an alternative habitat for benthic invertebrates: Species specific responses to a transient resource. Journal of
Experimental Marine Biology and Ecology, 248: 79-104, doi: 10.1016/S0022-0981(00)00155-6

Normant, M., Korthals, J., Szaniawska, A. (2007). Epibiota associated with setae on Chinese mitten crab claws (Eriocheir sinensis $\mathrm{H}$. Milne-Edwards, 1853): a first record. Oceanologia 49:137-143

Nunes, A.L., Katsanevakis, S., Zenetos, A. and Cardoso, A.C. (2014). Gateways to alien invasions in the European seas. Aquatic Invasions Vol. 9(2): 133-144. doi: http://dx.doi.org/10.3391/ ai.2014.9.2.02

Nyberg, C.D., Thomsen, M.S. and Wallentinus, I. (2009). Flora and fauna associated with the introduced red alga Gracilaria vermiculophylla. European Journal of Phycology 44: 395-403, doi:10.1080/09670260802592808

Patoka, J., Bláha, M., Devetter, M. et al. (2015). Aquarium hitchhikers: attached commensals imported with freshwater shrimps via the pet trade. Biol Invasions, 18:457-461. doi 10.1007/s10530-015-1018-9

Pejchar, L. and Mooney, H.A. (2009). Invasive species, ecosystem services and human well-being. Trends in Ecology and Evolution. 24 (9), 497-504. doi:10.1016/j.tree.2009.03.016

Potgieter, L.J., Gaertnera, M., O'Farrell, P.J. and Richardson, D.M. (2019). Perceptions of impact: Invasive alien plants in the urban environment. Journal of Environmental Management, 229: 76-87. https://doi.org/10.1016/j.jenvman.2018.05.080

Preston, C.D., Pearman, D.A. and Hall, A.R. (2004). Archaeophytes in Britain. Botanical Journal of the Linnean Society, 145: 257 294.

Pysek, P. and Richardson, D.M. (2010). Invasive species, environmental change and management, and health. Annu. Rev. Environ. Resour. 35:25-55. doi: 10.1146/annurevenviron-033009-095548

Pysek, P., Hulme, P.E., Simberloff, D. et al. (2020). Scientists' warning on invasive alien species. Biol. Rev. (2020), pp. 000000. 1. doi: $10.1111 /$ brv. 12627

Rastegary, M. (2017). The ballast water management convection and its impacts on the shipping industry. Payam Darya, Vol. 5: 40-59.

Rech, S., Borrell, Y. and Garcia-Vazquez, E. (2016). Marine litter as a vector for non-native species: What we need to know. Mar: Pol. Bull. 113(1-2): 40-43. http://dx.doi.org/10.1016/j. marpolbul.2016.08.032

Reise, K., Buschbaum, C., Buttger, H. and Wegner, M.K. (2017). Invading oysters and native mussels: from hostile takeover to compatible bedfellows. Ecosphere, Vol. 8(9), Article e01949

Richardson, D.M., Cambray, J.A., Chapman, R.A., Dean, W.R.J., Griffiths, C.L., Le Maitre, D.C., Newton, D.J. and Winstanley, T.J. (2003). Vectors and pathways of biological invasion in South Africa - past, future and present. In Ruiz, G. and Carlton, J. (Eds.). Invasive species: vectors and management strategies. Island Press, Washington D.C. pp. 292-349.

Richardson, D.M., Pysek, P. and Carlton, J.T. (2011). A compendium of essential concepts and terminology in invasion ecology. In Richardson, D.M. (Ed.). Fifty Years of Invasion Ecology: The Legacy of Charles Elton, $1^{\text {st }}$ edition. Blackwell Publishing Ltd. Chapter 30: pp. 409-420.

Ruesink, J.L., Feist, B.E., Harvey, C.J., et al. (2005). Changes in productivity associated with four introduced species: ecosystem transformation of a 'pristine' estuary. Mar. Ecol. Prog. Ser. 322:203-215.

Ruiz, G.M., Carlton, J.T., Grosholz, E.D. and Hines, A.H. (1997). Global invasion of marine and estuarine habitats by nonindigenous species: mechanisms, extent, and consequences. Amer. Zool. 37: 621-632

Ruiz, G.M., Fofonoff, P.W., Carlton, J.T. et al. (2000). Invasion of coastal marine communities in North America: apparent patterns, processes, and biases. Annu. Rev. Ecol. Syst. 31: 481531 
Russell, J.C. and Blackburn, T.M. (2017). The rise of invasive species denialism. Trends in Ecology \& Evolution, 32(1): 3-6

Scheiffarth, G., Ens, B., Schmidt, A. (2007). What will happen to birds when Pacific oysters take over the mussel beds in the Wadden Sea? Wadden Sea Newsletter 1: 10-14

Seebens, H., Gastner, M.T. and Blasius, B. (2013). The risk of marine bioinvasion caused by global shipping. Ecology Letters, 16: 782-790. doi: 10.1111/ele.12111

Shackleton, R.T., Richardson, D.M., Shackleton, C.M., Bennett, B., Crowley, S.L., Dehnen-Schmutz, K., et al. (2019). Explaining people's perceptions of invasive alien species: A conceptual framework. Journal of Environmental Management. 229: 1026. https://doi.org/10.1016/j.jenvman.2018.04.045

Shelton, W.L., and Rothbard, S. (2006). Exotic species in global aquaculture - A review. Israeli Journal of AquacultureBamidgeh, 58, 3-28.

Shuai, F., Li, X., Liu, Q., Zhu, S., Wu, Z., and Zhang, Y. (2018). Nile tilapia (Oreochromis niloticus) invasions disrupt the functional patterns of fish community in a large subtropical river in China. Fish Manag Ecol., 26:578-589. doi: 10.1111/ fme. 12368

Simberloff, D. (2006). Risk assessments, blacklists, and white lists for introduced species: are predictions good enough to be useful? Agricultural and Resource Economics Review, 35(1): $1-10$

Simoes-Vitule, J.R., Freire, C.A., and Simberloff, D. (2009). Introduction of non-native freshwater fish can certainly be bad. Fish and Fisheries, 10, 98-108. https://doi.org/10.1111/j. 1467-2979.2008.00312.x

Sladonja, B., Poljuha, D. and Uzelac, M. (2018). Non-native invasive species as ecosystem service providers. Ecos. Services and Global Ecology. 3, 39-59. http://dx.doi.org/ 10.5772/intechopen.75057

Smaal, A.C., Kater, B., Wijsman, J. (2009). Introduction, establishment and expansion of the Pacific oyster Crassostrea gigas in the Oosterschelde (SW Netherlands). Helgol Mar Res, 63:75-83

Stachowicz, J.J., Fried, H., Osman, R.W. and Whitlatch, R.B. (2002). Biodiversity, invasion resistance, and marine ecosystem function: reconciling pattern and process. Ecology, 83(9): 2575-2590

Starling, F., Lazzaro, X., Cavalcanti, C., and Moreira, R. (2002). Contribution of omnivorous tilapia to eutrophication of a shallow tropical reser- voir: Evidence from a fish kill. Freshwater Biology, 47, 2443-2452. https://doi.org/10.1046/ j.1365-2427.2002.01013.x

Thomas, C.D. (2013). The anthropocene could raise biological diversity. Nature, 502.

Thomsen, M.S., Stæhr, P., Nyberg, C.D., Krause-Jensen, D., Schwærter, S. and Silliman, B. (2007). Gracilaria vermiculophylla in northern Europe, with focus on Denmark, and what to expect in the future. Aquatic Invasions 2: 83-94, doi:10.3391/ai.2007.2.2.1

Thomsen, M.S. (2010). Experimental evidence for positive effects of invasive seaweed on native invertebrates via habitatformation in a seagrass bed. Aquatic Invasions, Vol. 5(4): 341346. doi: 10.3391/ai.2010.5.4.02

Troost, K. (2010). Causes and effects of a highly successful marine invasion: case-study of the introduced Pacific oyster Crassostrea gigas in continental NW European estuaries. J Sea Res, 64:145-165 van der Zee, E.M., van der Heide, T., Donadi, S., Eklof, J.S. et al. (2012). Spatially extended habitat modification by intertidal reef- building bivalves has implications for consumerresource interactions. Ecosystems, 15: 664-673. doi: 10.1007/s10021-012-9538-y

Vane, M., and Runhaar, H.A.C. (2016). Public support for invasive alien species eradication programs: Insights from the Netherlands. Restoration Ecology, 24, 743-748. https://doi. $\operatorname{org} / 10.1111 /$ rec.12379

Vitule, J.R.S., Freire, C.A., and Simberloff, D. (2009). Introduction of non-native freshwater fish can certainly be bad. Fish and Fisheries, 10, 98-108. https://doi.org/10.1111/j.1467-2979. 2008.00312.x

Ward, J.M. and Ricciardi, A. (2007). Impacts of Dreissena invasions on benthic macroinvertebrate communities: a meta-analysis. Diversity and Distributions, 13: 155-165.

Waser, A., Deuzeman, S., wa Kangeri, A.K., van Winden, E., Postma, J., de Boer, P., van der Meer, J., Ens, B.J. (2016). Impact on bird fauna of a non-native oyster expanding into blue mussel beds in the Dutch Wadden Sea. Biological Conservation, 202: 3949, https://doi.org/10.1016/j.biocon.2016.08.007

William, S.L., Davidson, I.C., Pasari, J.R. et al. (2018). Managing multiple vectors for marine invasions in an increasingly connected world. BioScience, Vol. 63(12): 952-966.

Wonham, M.J., O' Connor, M. and Harley, C.D.G. (2005). Positive effects of a dominant invader on introduced and native mudflat species. Mar. Ecol. Prog. Ser., Vol. 289: 109-116

Xiong, W., Shen, C., Wu, Z., et al. (2017) A brief overview of known introductions of non-native marine and coastal species into China. Aquatic Invasion, 12(1): 109-115. doi: http://doi.org/ 10.3391/ai.2017.12.1.11

Xu, P. and Ming, J. (2018). Status and trends of the tilapia farming industry development. In: Gui, J., Tang, Q., Li, Z., Liu, J., De Silva, S.S. (eds), Aquaculture in China. John Wiley \& Sons Ltd, UK, pp 402-420, https://doi.org/10.1002/9781119120759. ch4_4

Zengeya, T.A., Robertson, M.P., Booth, A.J., and Chimimba, C.T. (2013). Ecological niche modeling of the invasive potential of Nile tilapia Oreochromis niloticus in African river systems: Concerns and implications for the conservation of indigenous congener- ics. Biological Invasions, 15, 1507-1521. https://doi.org/10.1007/ s10530-012-0386-7

\section{Declarations}

\section{Funding statement}

This research did not receive any specific grant from funding agencies in the public, commercial, or not-for-profit sectors.

\section{Conflict of interest}

The authors declare no known conflict of financial interest or personal relationships that could have appeared to influence the work reported in this paper.

\section{Additional information}

Reprints and permission information is available at https://mri.lipi.go.id

Publisher's Note: Indonesian Institute of Sciences remains neutral with regard to jurisdictional claims in published maps and institutional affiliations. 
This page is intentionally left blank 